\title{
NONSPECIFIC STIMULATION OF RESISTANCE OF MICE TO INFECTION BY LIPOPOLYSACCHARIDE OF BORDETELLA BRONCHISEPTICA INCORPORATED INTO LIPOSOMES
}

\author{
M. Toman, J. Turánek and P. Hořavová \\ Veterinary Research Institute, Hudcova 70, 62132 Brno
}

Received November 12, 1993

\begin{abstract}
Toman M., J. Turánek, P. Hơ̆a vová: Nonspecific Stimulation of Resistance of Mice to Infection by Lipopolysacharide of Bordetella bronchiseptica Incorporated into Liposomes. Acta vet. Brno, 63, 1994: 71-79.

A phenolic extract containing lipopolysaccharide and residual nucleic acids (BBE-LPS) was prepared from selected strains of Bordetella bronchiseptica. Toxicity and immunostimulatory activity of the free extract and the extract incorporated into large unilamellar (LUV) and multilamellar (MLV) liposomes were tested in laboratory animals. The free extract significantly enhanced the resistance of mice to infections with $P$. multocida and pseudorabies virus at doses down to $1 \mathrm{gg}$ per animal. Incorporation into liposomes slightly reduced the toxicity of the extract. The incorporated extract enhanced the resistance to infection in mice, but its activity did not exceed that of the free extract.
\end{abstract}

\section{Immunostimulation, toxicity, lipopolysaccharide, liposome, mouse, resistance to infection}

Bordetella pertussis is one of the best known bacterial species showing a non-specific immunostimulatory activity described for the first time in the late forties (Gre e n berg and Fle ming 1947). This activity was later confirmed in several model systems in vitro and experiments aimed at the enhancement of resistance to infection or antibody responses to weak antigens (A th a na siades 1977; Kirchner et al. 1978; B o m ford 1980; W inters et al. 1985; B a g get et al. 1986).

In veterinary medicine, a similar immunostimulatory activity was demonstrated in the related species $B$. bronchiseptica. Adjuvant effects were described in mice immunized with tetanus toxoid ( $\mathrm{M}$ a $\mathrm{g}$ y a $\mathrm{r}$ et al. 1983) and in cattle vaccinated against bovine virus diarrhoea ( $\mathrm{Ch}$ e $\mathrm{n}$ et al. 1985). Recently, non-specific immunostimulatory activity of $B$. bronchiseptica has been described in mice (Wieler et al. 1990; To ma $\mathrm{n}$ et al. 1990).

Two strains of $B$. bronchiseptica with pronounced immunostimulatory effects were selected in our previous experiments (Tom an et al. 1990). The strains markedly enhanced the resistance of mice to infections with virulent strains of Pasteurella multocida. The immunostimulatory effects were confirmed also in model experiments using sublethally irradiated mice. The treatment with $B$. bronchiseptica bacterin $24 \mathrm{~h}$ prior to irradiation resulted in an earlier and accelerated regeneration of lymphoid tissues, as demonstrated by higher spleen weights, a rapid increase of peripheral lymphocyte counts and a high chemiluminiscent activity on post-irradiation day 6. Effects of bacterin B. bronchiseptica at various doses and in combinations with other substances were also examined in 2-month-old clinically normal calves. The treatment induced an increase of peripheral leukocyte counts after $24 \mathrm{~h}$ and enhanced phagocytosis of synthetic particles and chemiluminiscent activity on post-treatment days $2-4$.

The aim of the experiments presented here was to determine to what degree lipopolysaccharides (LPS) were responsible for the immunostimulatory activity of the $B$. bronchiseptica strains under study. Regarding the known side effects of LPS of Gram-negative bacteria, we compared the toxicity and the immunostimmulatory activity of a free extract and an extract incorporated into liposomes.

\section{Materials and Methods}

Extract of Bordetella bronchiseptica

The strains of $B$. bronchiseptica used in the experiments were obtained from the Czechoslovak Collection of Animal Pathogenic Microorganisms (codes CCM 6229 and CCM 6230). They showed growth in Phase I, agglutinated bovine erythrocytes and produced adenylate cyclase and cytotoxin. The strain 6229 was weak producer and the strain 6230 a strong producer of necrotoxin. The strains were propagated in the liquid medium BHI (Difco) and, for extraction, used as a mixture of two strains. A B. bronchiseptica extract (BBE-LPS) was prepared by phenolic extraction at $68^{\circ} \mathrm{C}$ (Westphal et al. 1952). The water phase was dialysed against flowing water, condensed by ultrafiltration (Amicon) through the membrane PM 10 and precipitated with ethanol in the presence of sodium acetate. The precipitate was washed with methanol, acetone and ether. 
Liposomes and incorporation of extract

Large unilamellar liposomes (LUV) were prepared using the detergent technique; $96 \mathrm{mg}$ of phospholipid were suspended in $5.5 \mathrm{ml}$ of physiological saline; $69 \mathrm{mg}$ of deoxycholate were added and, after $1 \mathrm{~h}$ mixing in a sealed vessel, the clarified solution was centrifuged at 7000 r.p.m. for $20 \mathrm{~min}$. The supernatant was transferred into a home-made, magnetically stirred ultrafiltration chamber adapted for the continuous through flow. The ultrafiltration membrane PM 10 (cut off $10 \mathrm{kDa}$, Amicon) was placed into the cell. Physiological saline was flowed through the cell and a P-500 pump (Pharmacia LKB) was used to maintain a constant flow rate of $20 \mu \mathrm{l} / \mathrm{min}$. The cell allows a precise control of dialysis rate. After $20 \mathrm{~h}$ of dialysis (to remove detergent), the liposomes were withdrawn from the cell by a sterile syringe.

Multilamellar liposomes (MLV) were prepared using the technique hydration of lipid film. A mixture of $100-300 \mathrm{mg}$ of phospholipids in $5 \mathrm{ml}$ of distilled chloroform was evaporated in a round-bottom flask at $37^{\circ} \mathrm{C}$. The resulting phospholipid film was hydrated with $1 \mathrm{ml}$ of HEPES buffer $(20 \mathrm{nM}, \mathrm{pH} 7.2)$ containing various amounts of BBE-LPS. The homogeneity of liposomes and the rate of incorporation of BBE-LPS were increased by sonication in a water bath at $8^{\circ} \mathrm{C}$ or subsequent five-fold freezing-thawing, both procedures being followed by filtration through membrane filters 0.22 and 0.45 um ( Tu ránek 1993).

The efficiency of LPS incorporation was measured using a fluorescein labelled BBE-LPS and the luminiscence spectrometer Perkin Elmer LS-50. The size and homogeneity of liposomes were checked by electron microscopy using the negative staining technique.

\section{Safety tests}

The Berlin test was used (B erlin 1962). The tested material $(0.2 \mathrm{ml})$ was injected intraperitoneally to each $\mathrm{Balb} / \mathrm{c}$ mouse in each group of 10 animals. The mice were weighed before the treatment and 2, 4, and 7 days the reafter. The mice were then necropsied and examined for contingent lesions in abdominal organs. The evaluation of the test was based on comparisons of live weight gains in experimental and control groups; the latter received physiological saline instead of the material tested.

Pyrogenicity of the BBE-LPS was tested in rabbits using the method described in the Czechoslovak Pharmacopoeia 4 . Body temperatures were measured before the treatment in 3 rabbits three times at 15 min intervals. The differences in individual rabbits never exceeded $0.5^{\circ} \mathrm{C}$.

Body temperatures were then measured 15 and $30 \mathrm{~min}$ and 1, 2, 3,6 and $24 \mathrm{~h}$ after intravenous administration of $2 \mathrm{ml}$ of BBE-LPS.

\section{Resistance-to-infection test in mice}

Pasteurella multocida (strain 6254, obtained from the Czechoslovak Collection of Microorganisms, Brno) and pseudorabies virus (strain V8 Plzeň, obtained from Dr. Smíd, Veterinary Research Institute, Brno) were used in challenge experiments.

$10 \mathrm{Balb} / \mathrm{c}$ mice in each group received $0.1 \mathrm{ml}$ of the tested substance intraperitoneally and, $24 \mathrm{~h}$ later, were challenged with $0.2 \mathrm{ml}$ of a suspension containing $10^{9} \mathrm{CFU}$ of $P$. multocida per $1 \mathrm{ml}$ or with $0.2 \mathrm{ml}$ of a suspension of pseudorabies virus with a titre of approx. $10^{-5}$ TCID50 for rabbit kidney cells. Death rates were recorded daily for 5 (P. multocida) or 7 (pseudorabies virus) days and compared with that in control mice receiving physiological saline instead of the stimulant.

\section{Results}

\section{Physical and chemical properties of the extract and liposomes}

The phenolic extraction was a yellowish powder showing a poor solubility in water. LPS and a small amount of nucleic acids were identified as its significant components by gel permeation chromatography.

The liposomes prepared by the detergent technique were unilamellar and had a fairly uniform size of approx. $100 \mathrm{~nm}$. Those prepared by the technique of lipid film hydration were multilamellar and their size ranged between 100 and $1500 \mathrm{~nm}$. The size heterogeneity was partly reduced by repeated freezing-thawing and subsequent filtration through membrane filters.

The efficiency of incorporation of BBE-LPS into liposomes prepared by both techniques was high, ranging between 72 and $88 \%$.

\section{Product safety}

No deaths occurred and no lesions were detected in mice which received up to $100 \mu \mathrm{g}$ of BBE-LPS intraperitoneally. However, the extract inhibited growth, especially during the first $48 \mathrm{~h}$ after the administration, and this effect was demonstrable at dosages down to 
$5 \mu \mathrm{g}$ per animal (Table 1). Pyrogenic effects of BBE-LPS were observed in rabbits after intravenous administration of doses down to $1 \mu \mathrm{g}$ per $1 \mathrm{~kg}$ live weight.

The growth inhibiting effect was reduced in mice treated with 5 ug of liposome-incorporated BBE-LPS. The pyrogenicity of $5 \mu \mathrm{g}$ liposome-incorporated BBE-LPS was also lower but remained unaltered at higher dosages.

Administration of empty liposomes did not induce any lesions or growth inhibition in mice or body temperature elevation in rabbits.

Table 1

Safety of preparations used

\begin{tabular}{|c|c|c|c|c|c|}
\hline & \multicolumn{3}{|c|}{ Berlin test ${ }^{a)}$} & \multicolumn{2}{|c|}{ Pyrogenicityb) } \\
\hline & \multirow{2}{*}{ dose } & \multicolumn{2}{|c|}{ after } & \multirow{2}{*}{ dose } & \multirow[b]{3}{*}{$\left.1.34^{*}\right)$} \\
\hline & & 2 days & 7 days & & \\
\hline B. Bronchiseptica & $2 \times 10^{8} \mathrm{CFU} /$ mouse & $\left.-0.62^{*}\right)$ & $\left.-2.00^{*}\right)$ & $10^{9} \mathrm{CFU} / \mathrm{kg}$ & \\
\hline \multirow[t]{3}{*}{ BBE-LPS } & $50 \mathrm{yg} / \mathrm{mouse}$ & $\left.-1.65^{*}\right)$ & $\left.-4.00^{*}\right)$ & $50 \mathrm{ug} / \mathrm{kg}$ & $\left.1.82^{*}\right)$ \\
\hline & $10 \mathrm{yg} / \mathrm{mouse}$ & $\left.-0.92^{*}\right)$ & $\left.-3.92^{*}\right)$ & $10 \mathrm{yg} / \mathrm{kg}$ & $\left.1.48^{*}\right)$ \\
\hline & $5 \mathrm{yg} / \mathrm{mouse}$ & $\left.-0.67^{*}\right)$ & -1.72 & 1 ug/kg & $\left.1.62^{*}\right)$ \\
\hline LIPOSOMES & & +0.05 & -0.02 & & 0.39 \\
\hline \multirow{2}{*}{$\begin{array}{l}\text { Liposome- } \\
\text { incorporated } \\
\text { BBE-LPS }\end{array}$} & $10 \mathrm{yg} /$ mouse & $\left.-1.42^{*}\right)$ & $\left.-1.01^{*}\right)$ & $10 \mathrm{\mu g} / \mathrm{kg}$ & $\left.1.45^{*}\right)$ \\
\hline & $5 \mathrm{yg} / \mathrm{mouse}$ & $-0.62 *)$ & +0.10 & $1 \mu g / k g$ & 0.88 \\
\hline
\end{tabular}

Legends: a) Weight gain (g) differences between the experimental and control groups of mice

b) Maximum temperature increase $\left({ }^{\circ} \mathrm{C}\right)$

*) Significant difference $(\mathrm{p}<0.05)$

Resistance-to-infection stimulation in mice

BBE-LPS markedly increased the resistance of mice to infection at doses down to $1 \mathrm{ug}$ per animal (Fig. 1 and 2). Survival rates were 80-90 per cent against 10-20 per cent of control animals, and 90 per cent against 40 per cent of control animals in mice challenged with $P$. multocida and pseudorabies virus, respectively.

Stimulating effects of empty liposomes depended on the preparation techniques (Fig. 3). The best results were obtained with liposomes prepared by the detergent technique and with those prepared by lipid film hydration followed by five-fold freezing-thawing. Lower stimulation effects were obtained with liposomes prepared by evaporation followed by sonication and filtration.

Pronounced stimulation was observed in mice treated with liposome-incorporated BBE-LPS, but the effect did not exceed that of free BBE-LPS (Fig. 4). The stimulating effect of empty liposomes was higher than that of free or liposome-incorporated BBE-LPS when the threshold dose of BBE-LPS (0.4 $\mu \mathrm{g} /$ mouse) was administered (Fig. 5). 


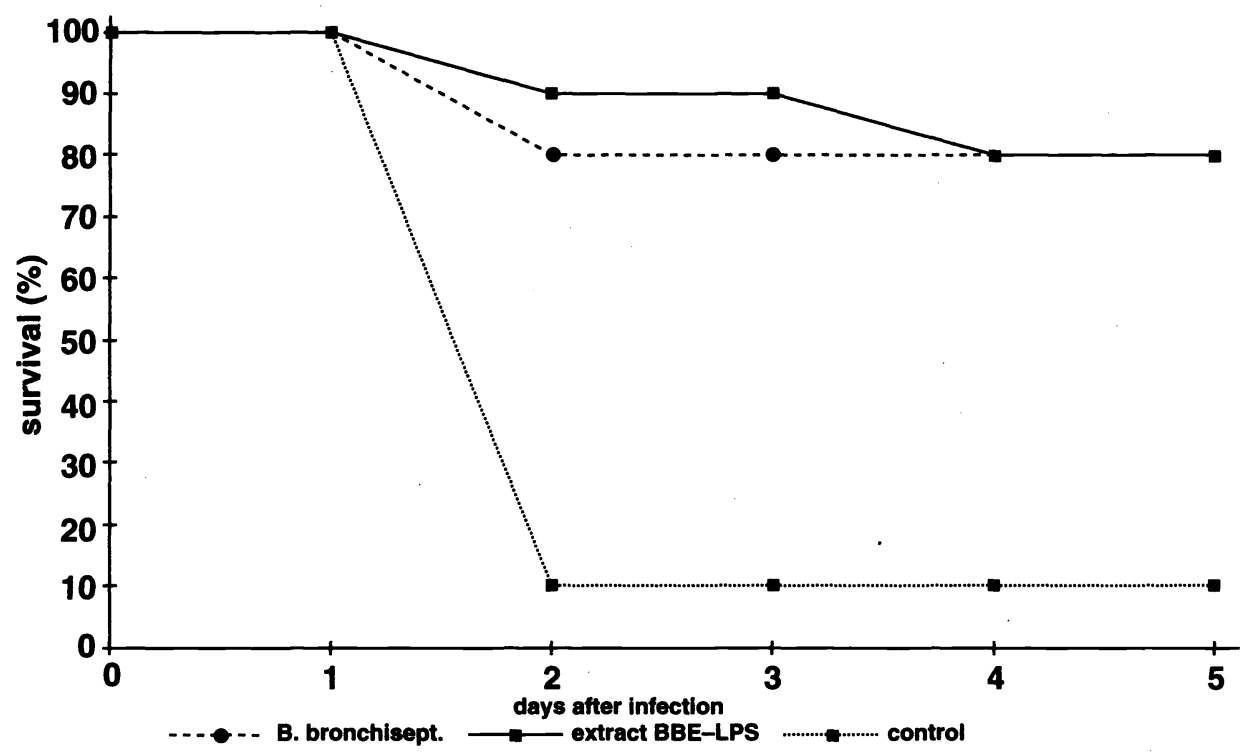

Fig. 1 Resistance to infection with P. multocida in mice stimulated by Bordetella bronchiseptica bacterin or extract BBE-LPS ( $1 \mu \mathrm{g} / \mathrm{mouse})$

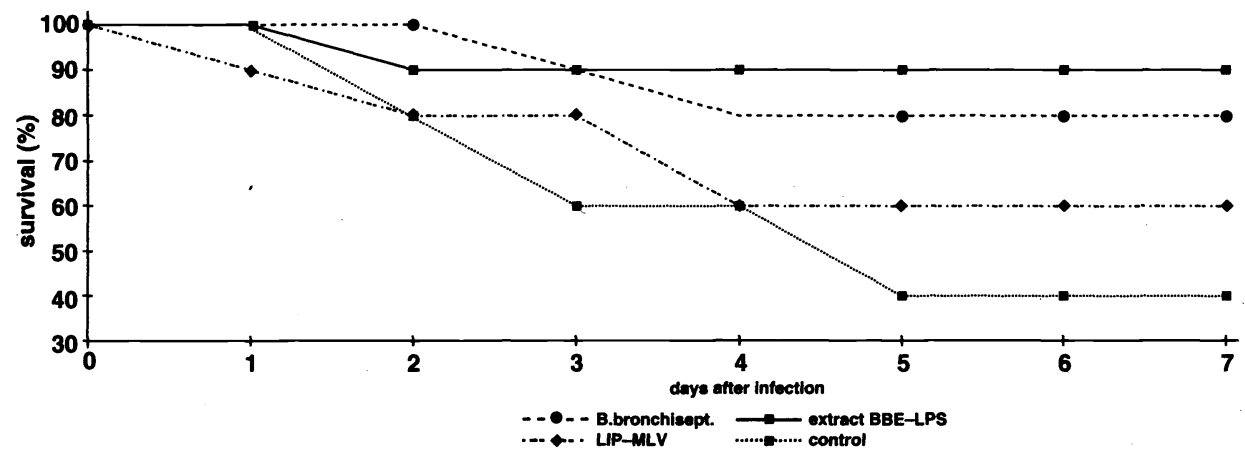

Fig. 2 Resistance to infection with pseudorabies virus in mice stimulated by Bordetella bronchiseptica bacterin or extract BBE-LPS ( $1 \mu \mathrm{g} / \mathrm{mouse})$ 


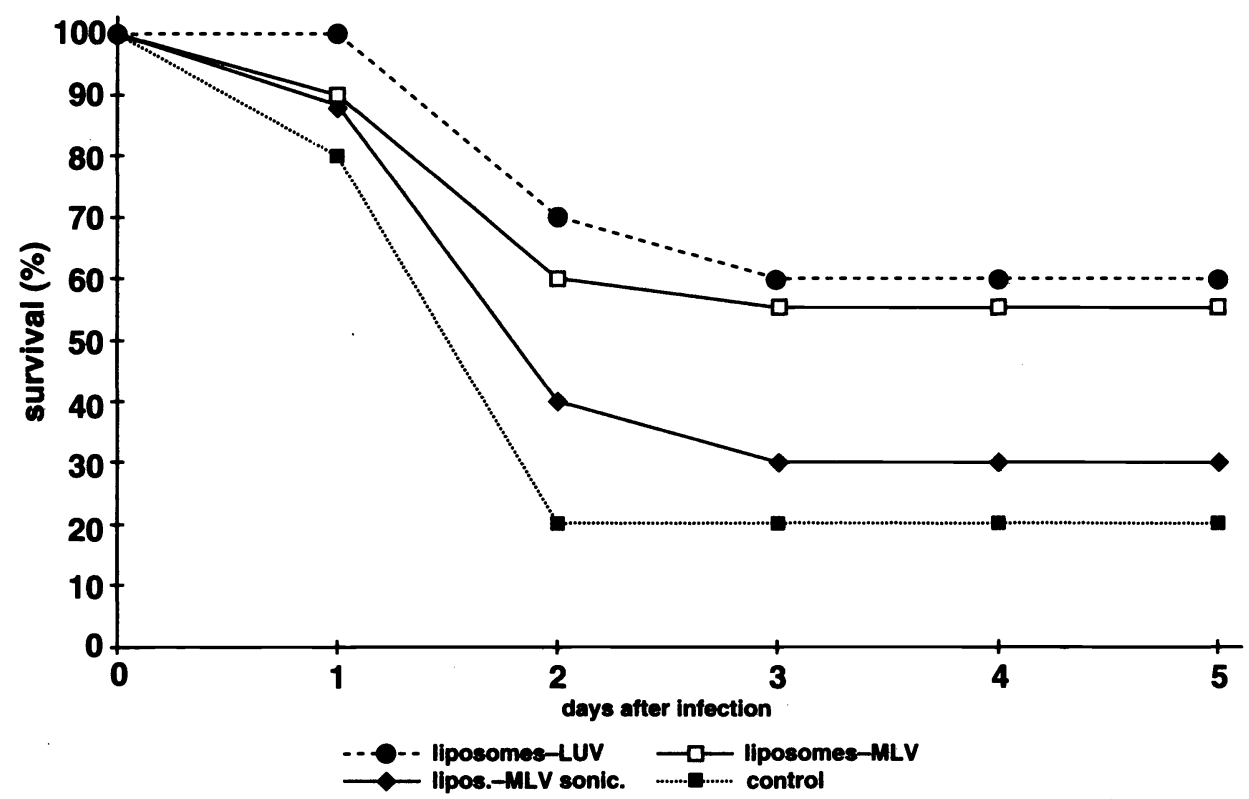

Fig. 3 Resistance to infection with $P$. multocida in mice stimulated by empty liposomes.

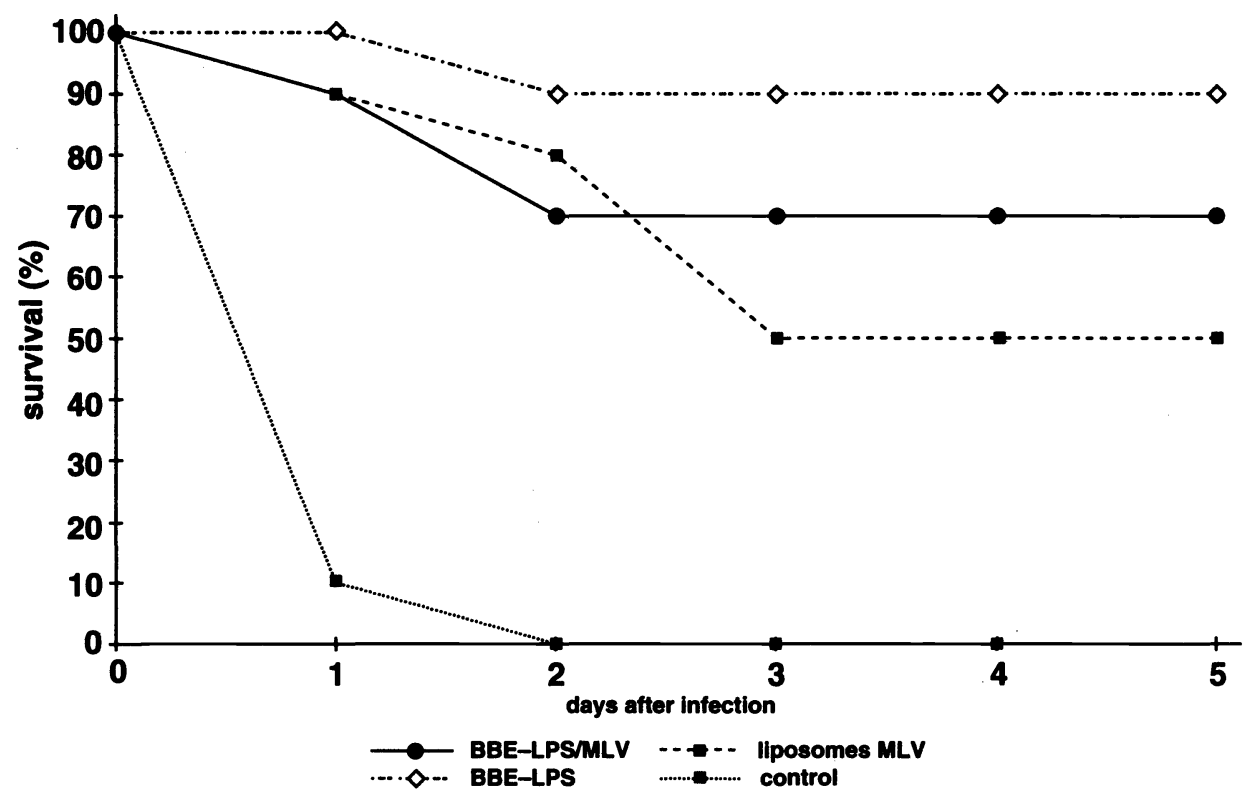

Fig. 4 Resistance to infection with $P$. multocida in mice stimulated by free extract BBE-LPS $(2 \mu \mathrm{g} / \mathrm{mouse})$ or extract incorporated into liposomes. 


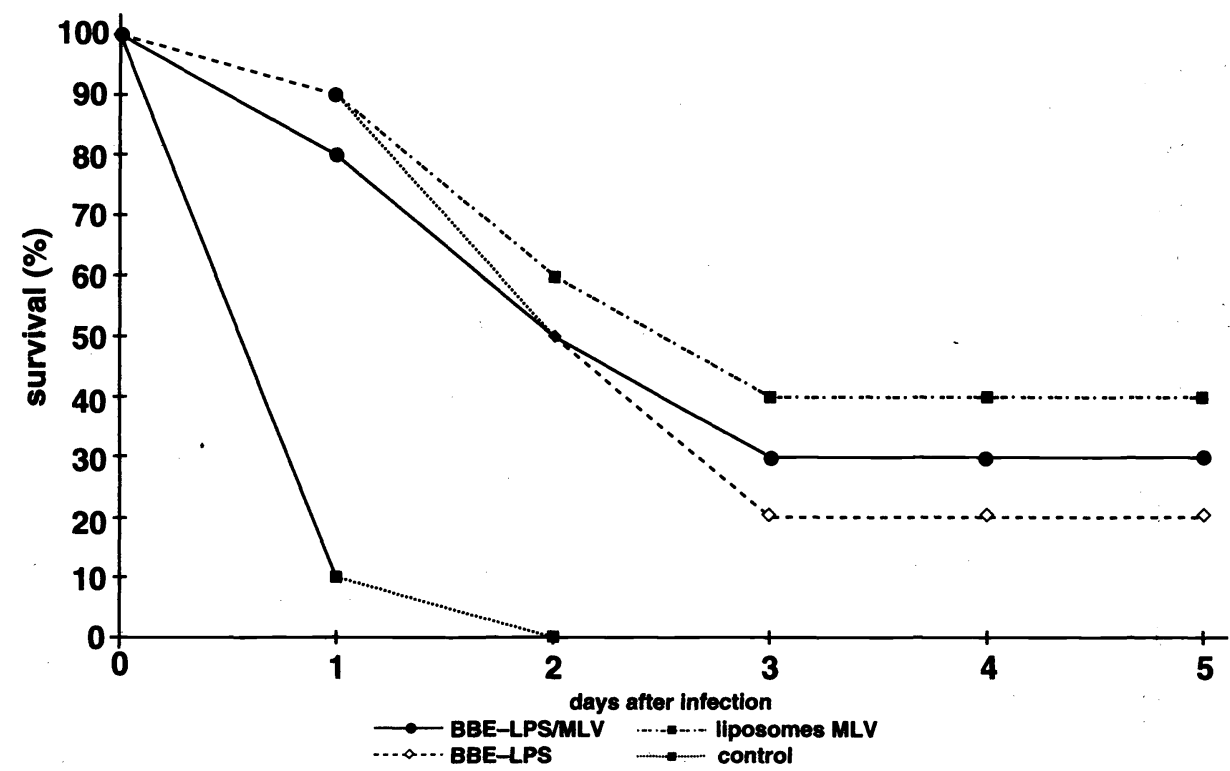

Fig. 5 Resistance to infection with P. multocida in mice stimulated by free extract BBE-LPS $(0.4 \mu \mathrm{g} / \mathrm{mouse})$ or extract incorporated into liposomes.

\section{Discussion}

Cell walls of Gram-negative bacteria are composed of lipopolysaccharides (LPS), containing polysaccharide, and the immunologically active lipid A. G a l a n os and his co-workers (1984) were the first who described the structure of the latter. Non-specific resistance to infection (A y me et al. 1980; Le Garrec 1986; B aggett et al. 1986, Nakatsuka et al. 1989) and tumours ( $\mathrm{N}$ a k a t s u k a et al. 1989) was enhanced already by minute amounts of LPS (1 ugg). Also well known is the adjuvant activity of LPS reflected in the enhancement of both humoral and cell-mediated immune reactions (Le Garrec 1986).

LPS activates a number of immunological events by stimulating the proliferation of lymphocytes, above all as a polyclonal activator of $\mathrm{B}$ lymphocytes ( $\mathrm{Ca}$ vallo and $\mathrm{Granholm}$, 1990), by increasing the activity of natural killer cells (O k a mu ra et al. 1987; Le Garrec 1986) and by stimulating migration and chemiluminiscence of polymorphonuclear cells (Klesius et al. 1984; Kappet al. 1987; Aida and Pabst 1990). However, the major mechanism obviously lies in its effect on macrophages producing interleukin 1 (Fla d 1990; J o h a n s en et al. 1990). Interleukin 1 activates further subsystems and, in the general context, induces a number of clinical effects including resistance to infections or tumours.

In our experiments, some of the activities were also demonstrated in BBE-LPS which enhanced resistance to both bacterial and viral infections. The fact that the best effect was obtained by intraperitoneal administration of both the immunostimulant and the challenge dose confirmed that its major mechanism of action is the activation of macrophages. In another series of experiments, stimulation of chemiluminescent activity and mitogenic activity in vit ro were observed (To m a n, unpublished data).

Immunostimulatory properties of LPS depend on the strain of bacteria from which it has been prepared. In our work we used LPS extracted from B. bronchiseptica which was found to be a very strong immunostimulant in comparison with other tested bacteria; it increased the LD50 of challenged $P$. multocida by up to two logs (T o m a n et al. 1990). There were 
also differences in the activities of various strains of $B$. bronchiseptica and of various batches of BBE-LPS (T o m a n, unpublished data).

Generally, the immunostimulatory activity of BBE-LPS was comparable with that of whole cells of $B$. bronchis eptic a although it was difficult to compare doses of whole cells and the extracted BBE-LPS. The activity of BBE-LPS was also similar to that of LPS described by other authors (A y m e et al. 1980; $\mathrm{Nak}$ a t su k a et al. 1989). The large differences in immunostimulatory activity of bacterins prepared from various strains of $B$. bronchiseptica and the fact that the activity of BBE-LPS was not fully identical with that of whole bacterial cells made us assume that some other immunologically active component(s) might be contained in $B$. bronchiseptica strains 6229 and 6230. Immunologically active units other than LPS were also demonstrated in B. pertussis, among them primarily the pertussis toxin also termed ,lymphocytosis promoting factor" (Le Garrec 1986; Oda and Higurashi 1988).

The prospects of field use of LPS as immunostimulants are rather limited owing to its high pyrogenicity and other side effects. We attempted to reduce the toxicity by incorporating BBE--LPS into liposomes used as carriers of drugs including LPS or lipid A, muramyl dipeptides and other immunostimulants (Dij ks t r a et al. 1987; R i c h a rd s et al. 1989; T s u ji moto et al. 1989; Nerome et al. 1990; Alving and Richards 1990). In our experiments a slight reduction of toxicity, reflected in an elevation of threshold concentrations inducing growth inhibition in mice and body temperature elevation in rabbits, was actually demonstrated by safety tests. The immunostimulatory activity of BBE-LPS, expressed in the enhancement of resistance to infection in mice, remained at approximately the same level after the incorporation.

It can be concluded that the extract BBE-LPS had strong immunostimulatory properties, increasing the resistance of mice against infection similarly to whole $B$. bronchiseptica cells. Nevertheless, we suppose that LPS is not the sole immunologically active component of bacterial strains and currently we are testing other structures of $B$. bronchiseptica and comparing LPS isolated from strains differing in their stimulatory activity in order to confirm or reject this supposition. Incorporation into liposomes slightly decreased the toxicity of the extract but did not increase immunostimulatory activity against infectionsin mice.

Acknowledgements

The authors thank Dr. B. Smíd for the identification of liposomes by electron microscopy.

\section{Nespecifická stimulace odolnosti myší proti infekci lipopolysacharidem Bordetella bronchiseptica v liposomech}

Z vybraných kmenů Bordetella bronchiseptica jsme připravili fenolový extrakt, který obsahoval lipopolysacharid (LPS) a zbytkové množství nukleových kyselin. Toxicitu a imunostimulační aktivitu volného extraktu nebo extraktu zabudovaného do velkých unilamelárních (LUV) nebo multilamelárních (MLV) liposomů jsme testovali na laboratorních zvířatech. Volný extrakt výrazně zvyšoval odolnost myši proti infekci P. multocida a viru Aujezskyho choroby, a to až do dávky $1 \mathrm{ugg} / \mathrm{myš}$. Po zabudování do liposomů se mírně snižovala toxicita extraktu. Extrakt v liposomech zvyšoval odolnost myší proti infekci, avšak aktivita nebyla vyšši než u volného extraktu.

\section{Неспецифическое стимулирование устойчивости мышей к инфекции липополисахаридом Bordetella bronchiseptica в липосомах}

На избранных штаммах Bordetella bronchiseptica нами была проготовлена фенольная вытяжка, содержащая липосахарид (LPS) и остаточное количество никлеиновых кислот. Ток- 
сичность и иммуностимулирующую активность свободной вытяжки или экстракта, введенного в крупные униламеллярные (LUV) или мультиламеллярные (MLV) липосомы, проверяли на лабораторных животных. Свободный экстракт существенно увеличивал устойчивость мышей к инфекции P. multocida и вируса болезни Ауески, а именно до дозы 1 мкг/мышь. После введения в липосомы незначительно понижалась токсичность экстракта. Экстракт в липосомах увеличивал устойчивость мышей к инфекции, однако акривность по сравнению со свободным экстрактом была не выше.

\section{References}

AIDA, Y.-PABST, M. J.: Priming of neutrophils by lipopolysaccharide for enhanced release of Superoxide. J. Immunol., 145, 1990, 3017-3025.

ALVING, C. R.-RICHARDS, R. L.: Liposomes containing lipid A: a potent nontoxic adjuvant for a human malaria sporozoite vaccine. Immunol. Lett., 25, 1990: 275-280.

ATHANASSIADES, T. J.: Adjuvant effect of Bordetella pertussis vaccine to sheep erythrocytes in mice: enhancement of cell mediated immunity by subcutaneous administration of adjuvant and antigen. Infect. Immun., 18, 1977: 416-423.

AYME, G.-CAROFF, M. -HABY, R.-HAEFFNER-CAVAILLON, N.-LE DUR, A.-MOREAU, M.-MUSET, -M.-MYNARD, M. C.-ROUMIANTZEFF, M.-SCHULZ, D.-SZABO, L.: Biological activities of fragments derived from Bordetella pertussis endotoxin: Isolation of a nontoxic, Schwartzman - negative lipid A possessing high adjuvant properties. Infect. Immun., 27, 1980: 739-745.

BAGGET, D. W.-LEBLANC, P. A.-ALLISON, F. S.-THOMLEY, M. J.-WINTERS, A. L.: Antiviral activity of Bordetella pertussis vaccine - elicited peritoneal exudate cells. J. Immunopharm., 8, 1986: 586-609.

BERLIN, B. S.: Tests for biologic safety of Arlacel A. Ann. Allerg., 20, 1962: 472-479.

BOMFORD, R.: The comparative selectivity of adjuvants for humoral and cell - mediated immunity. Clin, exp. Immunol, 39, 1980: 435-441.

CAVALLO, T.-GRANHOLM, N. A.: Lipopolysaccharide from Gram-negative bacteria enhances polyclonal B cell activation and exacerbates nephritis in MRL/pr mice. Clin. exp. Immunol, 82, 1990: 515-521.

CHEN, K. S.-JOHNSON, D. W.-MUSCOPLAT, C. C.: Adjuvant enhancement of humoral immune response to chemically inactivated bovine diarrhea virus. Can J. comp. Med., 49, 1985, 91-94.

DIJKSTRA, J.-MELLORS, J. W.-RYAN, J. L.-SZOKA, F. C.: Modulation of the biological activity of bacterial endotoxin by incorporation into liposomes. J. Immunol., 138, 1987: 2663-2670.

FLAD, H. D.: Induction of IL-1 by lipopolysaccharide (LPS) and its modulation by synthetic lipid A precursor la. Lymphokine Res., 9, 1990: 557-562.

GALANOS, C.-LEHMANN, V.-LUDERITZ, O.-RIETSCHEL, E.-WESTPHAL, O.- BRADE, H.-FREUDENBERG, M. A.-HANSEN-HAGGE, T.-LUDERITZ, T.-McKENZIE, G.-SCHADE, U.-STRITTMATTER, W.-TANAMOTO, K.-ZAHRINGER, U.-IMOTO, M.-YOSHIMURA, H.-YAMAMOTO, M.-SHIMAMOTO, T.-KUSUMOTO, S.-SHIBA, T.: Endotoxic properties of chemically synthesized lipid A part structures. Eur. J. Biochem., 140, 1984: p. 221-227.

GREENBERG, L.-FLEMING, D.: Increased efficiency of diphtheria toxoid when combined with pertussis vaccine. Can. J. Pub. Hlth., 38, 1947: 279-282.

JOHANSEN, K. A.-WANNEMUEHLER, M. J.-ROSENBUSCH, R. F.: Biological reactivity of Moraxella bovis lipopolysaccharide. Amer. J. vet. Res., 51, 1990: 46-51.

KAPP, A.-FREUDENBERG, M.-GALANOS, CH: Induction of human granulocyte chemiluminescence by bacterial lipopolysacharides. Infect. Immun., 55, 1987: 758-761.

KIRCHNER, H.-SCOTT, M. T.-MUNK, K.: Protection of mice against viral infection by Corynebacterium parvum and Bordetella pertussis. J. gen. Virol, 41, 1978: 97-104.

KLESIUS, P. H.-CHAMBERS, W. H.-SCHULTZ, R. D.: Effects of bacterial lipopolysaccharide on bovine polymorphonuclear neutrophil migration in vitro, Vel. Immunol. Immunopathol., 7, 1984: 239-244.

LE GARREC, Y.: Immunomodifiers of bacterial origin. Comp. Immun. Microbiol. Infect. Dis., 9, 1986: 137-141.

MAGYAR, T.-GÉRESI, M.-SEMJÉN, G.-SOLTEEZSKY, J.-RÉTHY, L. A.-RÉTHY, L.: Studies on the immunological adjuvant activity of Bordetella bronchiseptica in mice. Acta veter. hung., 31, 1983: 31-35.

NAKATSUKA, M.-KUMAZAWA, Y.-MATSUURA, M.-YUZURU HOMMA, J.-KISO, M.-HASEGAWA, A.: Enhancement of nonspecific resistance to bacterial infections and tumor regressions by treatment with synthetic lipid A subunit analogs. Critical role of $\mathrm{N}$ - and 3-0 linked acyl groups in 4-0-phosphono-D-glucosamine derivatives. Int. J. Immunopharmac., 11, 1989: 349-358.

NEROME, K.-YOSHIOKA, Y.-ISHIDA, M.-OKUMA, K.-OKA, T.-KATAOKA, T.-INOUE, A.-OYA, A.: Development of a new type of influenza subunit vaccine made by muramyldipeptide-liposome: enhancement of humoral and cellular immune responses. Vaccine, 8, 1990: 503-509.

ODA, M.-HIGURASHI, M.: Development of acellular pertussis vaccine in Japan. Acta Paed. Jap., 1988, 30: $136-142$. 
OKAMURA, H.-WADA, M.-NAGATA, K.-TAMURA, T.-SHOJI, K.: Induction of murine gamma interferon production by lipopolysaccharide and interleukin -2 in propionibacterium acnes - induced peritoneal exudate cells. Infect. Immun., 55, 1987: 335-341.

RICHARDS, R. L.-SWARTZ, M. G.-SCHULTZ, C.-HAYRE, M. D.-WARD, S. G.-BALLOU, W. R.-CHULAY, J. D.-HOCKMEYER, T. W.-BERMAN, S. L.-ALVING, C. R.: Immunogenicity of liposomal malaria 6 sporozoite antigen in monkeys: adjuvant effects of alumunium hydroxide and non-pyrogenic liposomal lipid A. Vaccine, 7, 1989: 506-511.

TOMAN, M.-KREJČ́, J.-MENŠIK, P.-ULMANN, L.: Nespecifická imunostimulační aktivita bakterinu Bordetella bronchiseptica v testech na myších a telatech. Vet. Med (Czech), 35, 1990: 537-546.

TSUJIMOTO, M.-KOTANI, S.-OKUNAGA, T.-KUBO, T.-TAKADA, H.-KUBO, T.-SHIBA, T.-KUSUMOTO, S.-TAKAHASHI, T.-GOTO, Y.-KINOSHITA, F.: Enhancement of humoral immune responses against viral vaccines by a non-pyrogenic 6-0-acyl-muramyldipeptide and synthetic low toxocity analogues of lipid A. Vaccine, 7, 1989: 39-48.

TURANEK, J.: Fast protein liquid chromatography as a tool for liposome preparation by the extrusion procedure. Anal. Biochem., 1993, in press.

WESTPHAL, O.-LUDERITZ, O.-BISTER, F.: Über die Extraktion von Bakterien mit Phenol/Wasser. Z. Naturf., 7B, 1952: 148-155.

WIELER, L.-BALJER, G.-BUTTNER, M.-ADLER, J.-MAYR, A.: Vergleichende Untersuchungen über die paraspezifische Immunostimulierung (Paramunisierung) durch Bakterienlysate in bakteriellen Infektionsmodellen und im Cytotoxizitatstest. J. Vet. Med. B, 37, 1990: 491-500.

WINTERS, A. L.-BAGGET, D. W.-BENJAMIN, W. R.-BROWN, H. K.-KLEIN, T. W.: Resistance to adenovirus infection after administration of Bordetella pertussis vaccine in mice. Infect. Immun., 3, 1985: 587-591. 